\title{
Evolution History of Gassan Volcano, Northeast Japan Arc
}

\author{
Ryo Oizumi ${ }^{1}$, Masao Ban ${ }^{2 *}$, Naoyoshi Iwata ${ }^{2}$ \\ ${ }^{1}$ Graduate School of Science and Technology, Yamagata University, Yamagata, Japan \\ ${ }^{2}$ Faculty of Science, Yamagata University, Yamagata, Japan \\ Email: *ban@sci.kj.ya magata-u.ac.jp
}

How to cite this paper: Oizumi, R., Ban, M. and Iwata, N. (2018) Evolution History of Gassan Volcano, Northeast Japan Arc. Open Journal of Geology, 8, 647-661. https://doi.org/10.4236/ojg.2018.87038

Received: June 4, 2018

Accepted: July 10, 2018

Published: July 13, 2018

Copyright (๑) 2018 by authors and Scientific Research Publishing Inc. This work is licensed under the Creative Commons Attribution-NonCommercial International License (CC BY-NC 4.0). http://creativecommons.org/licenses/by-nc/4.0/ (c) (i) (8) Open Access

\begin{abstract}
Evolution history of the volcano is essential not only to characterize the volcano, but also consider magma genesis beneath the volcano. Most of the stratovolcanoes in northeast Japan follow a general evolutional course: cone building, horse-shoe shaped caldera forming collapse, and post-caldera stages. However, the detailed history of each stage is not well investigated. We investigated evolution history of young edifice of Gassan volcano, representative stratovolcano in rear side of northeast Japan arc. Most of the products are lavas, which are divided into two groups by geomorphologic and geologic features. The former (Gassan lower lavas) is composed of relatively thin and fluidal lavas, whose original geomorphology remains a little, while the latter (Gassan upper lavas) is composed of relatively thick and viscous lavas, whose original geomorphology is moderately preserved. Based on geologic features, the upper lavas can be further divided into Gassan upper north lavas and upper summit lavas in ascending order. After the formation of the thick lavas, horse-shoe shaped caldera was formed by the instability of the edifice, probably triggered by fault activity. No evidence of post caldera activity inner part of it is observed. Based on $\mathrm{K}$-Ar data, estimated age of Gassan lower lavas is ca. 0.75 to ca. $0.6 \mathrm{Ma}$, those of Gassan upper north and upper summit lavas are ca. 0.60 to ca. $0.55 \mathrm{Ma}$ and ca. 0.55 to ca. $0.45 \mathrm{Ma}$. The eruption rate is estimated to be ca. $0.0004 \mathrm{~km}^{3} / 1000$ years in Gassan lower lavas and ca. 0.02 $\mathrm{km}^{3} / 1000$ years in Gassan upper summit lavas. These values are lower than the eruption rate of representative Japanese stratovolcanoes.
\end{abstract}

\section{Keywords}

Stratovolcano, Andesitic Lava, Evolution History, Gassan Volcano, NE Japan, K-Ar Age Dating

\section{Introduction}

The knowledge of evolution history of the volcano is fundamental not only to 
classify and characterize the volcano but also consider magma genesis. In island arc setting, main types of the volcano are stratovolcano with subordinate amount of caldera volcano. In terms of Japanese stratovolcanoes, it was proposed that these follow an evolution course: cone building, horse-shoe shaped caldera collapse, and post-caldera stages, based on geomorphologic features [1]. The magmatic composition changes from basaltic to andesitic-dacitic during cone building stage in representative volcanoes, but some lack basaltic activity. The andesitic-dacitic activity continues to the post-caldera stage. The caldera collapse occurs because of instability of the edifice consisting upper thick overlying lower basaltic products triggered by magma ascent, heavy rain fall, or big earthquake. Further, detailed geologic investigations of Japanese volcanoes suggested that the evolution course is much more complex. The Nasu and Chokai volcanoes follow above course repeatedly [2] [3]. Petrologic studies coupled with geologic study, Ishizuka (1999) and Ban et al. (2001) suggested that the single evolution course of the stratovolcano would correspond to a pulse of upwelling of mantle diapir beneath the volcano [3] [4]. The basaltic activity attributes to the magma formation by melting of the mantle, while the andesitic-dacitic activity results from mixing of felsic magma caused by crustal melting and the mantle derived basaltic magma.

While general evolution history has been investigated in many volcanoes in northeast Japan (e.g., [5]), detailed investigation of evolution history during each stage is not sufficient. We examined it in Gassan volcano, representative stratovolcano in rear arc side in northeast Japan arc.

\section{Geologic and Tectonic Setting}

Northeast Japan is one of representative subduction zones. In this zone, the Pacific Plate is subducting at an angle of ca. $30^{\circ}$ westward beneath the North American Plate and the Eurasian Plate. Many volcanoes are arranging NS direction, which is parallel to the Japan Trench. The volcanic front is situated ca. 100 $\mathrm{km}$ above the deep seismic plane of the Pacific Plate. Most of the volcanoes are distributed near the volcanic front and some are scattered on the rear arc side (e.g., [6] [7] [8]) (Figure 1). Looking at the distribution of volcanoes in northeast Japan arc more closely, the volcanoes near the front can be divided into several clusters (e.g., [6] [7] [8] [9] [10]) (Figure 1). One cluster is composed of $~ 10$ volcanoes and the size of one cluster is 30 to $60 \mathrm{~km}$ in diameter. The intervals of the clusters are $70-100 \mathrm{~km}$. Also, rear arc side volcanoes distribute only behind the clusters not behind the interval areas. This finger-like spatial distribution is interpreted as corresponding to that of the hot area (hot fingers) in the mantle wedge [10]. The seismic tomography studies supported the existence of the predicted hot fingers (e.g., [11] [12] [13]).

The across-arc zonal variation of chemical compositions of Quaternary basalts, for example the increase of incompatible elements, $\mathrm{K}_{2} \mathrm{O}$ and $\mathrm{Rb}$ etc. from the front to the rear arc side, has been recognized in northeast Japan arc 


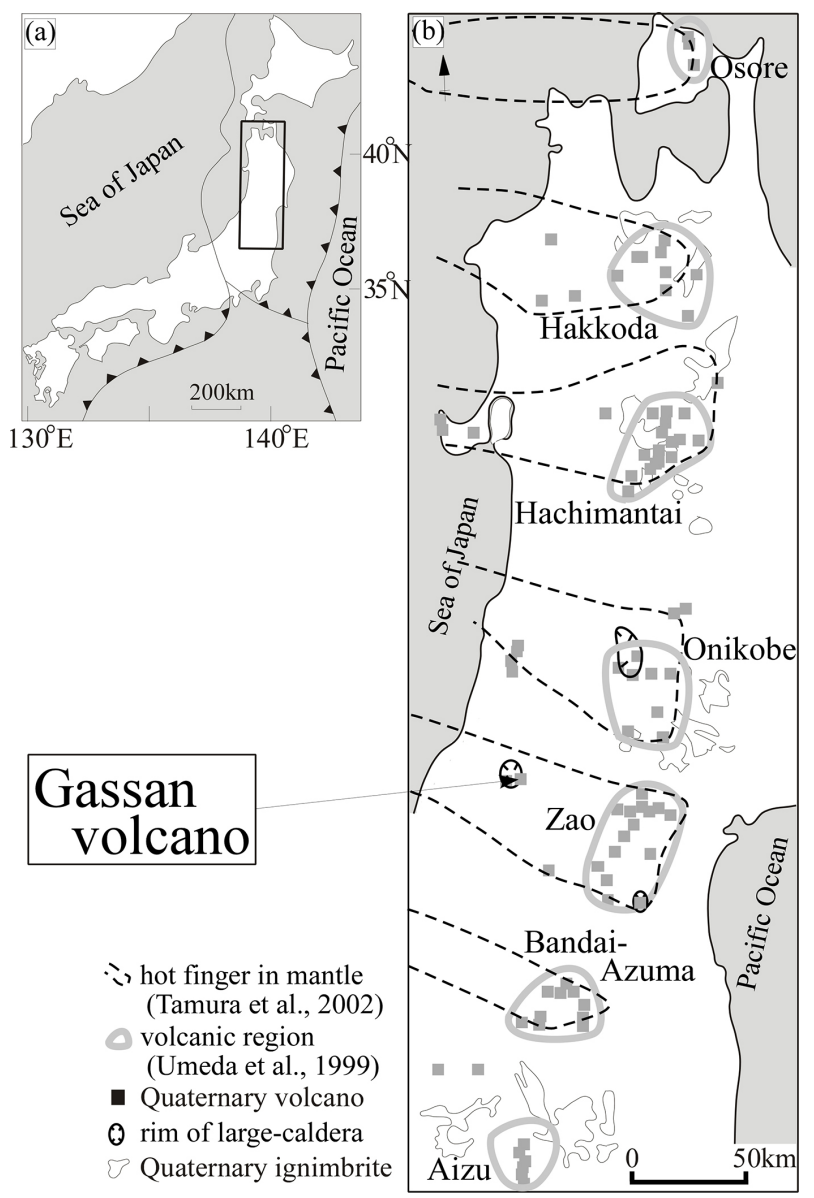

Figure 1. Locality map of the Gassan volcano [6] [7] [8].

(e.g., [14] [15] [16] [17]). This chemical zonation in basalt correlates with the depth of the down-going slab. This feature has been attributed to the combination of differences in degrees of partial melting of the mantle wedge and in dehydration phases both in the down-going slab and the down-dragged hydrous layer at the base of the mantle wedge (e.g., [18] [19]).

The Gassan volcano is composed of andesite with subordinate amount of dacite, and is divided into old and young edifices [20]. The K-Ar age for the young edifice is ca. $0.5 \mathrm{Ma}$ [21]. We examined the evolution history of the young edifice geologically, based on geomorphological and lithological data coupled with new K-Ar data.

\section{Geomorphology}

Geomorphologic map is shown in Figure 2. A horse-shoe shaped caldera, named Gassan caldera [20], is observed in the central part. The caldera is $2 \mathrm{~km}$ wide (EW) and $5 \mathrm{~km}$ long (NS), opening to the north. The maximum relative height of caldera wall is up to $400 \mathrm{~m}$. The volume of the collapsed edifice is estimated as $1.2 \mathrm{~km}^{3}$. The debris avalanche deposits are observed in the northern flank of this volcano (Figure 2(a)) [22]. Many hummocky hills of $\sim 300 \mathrm{~m}$ in 


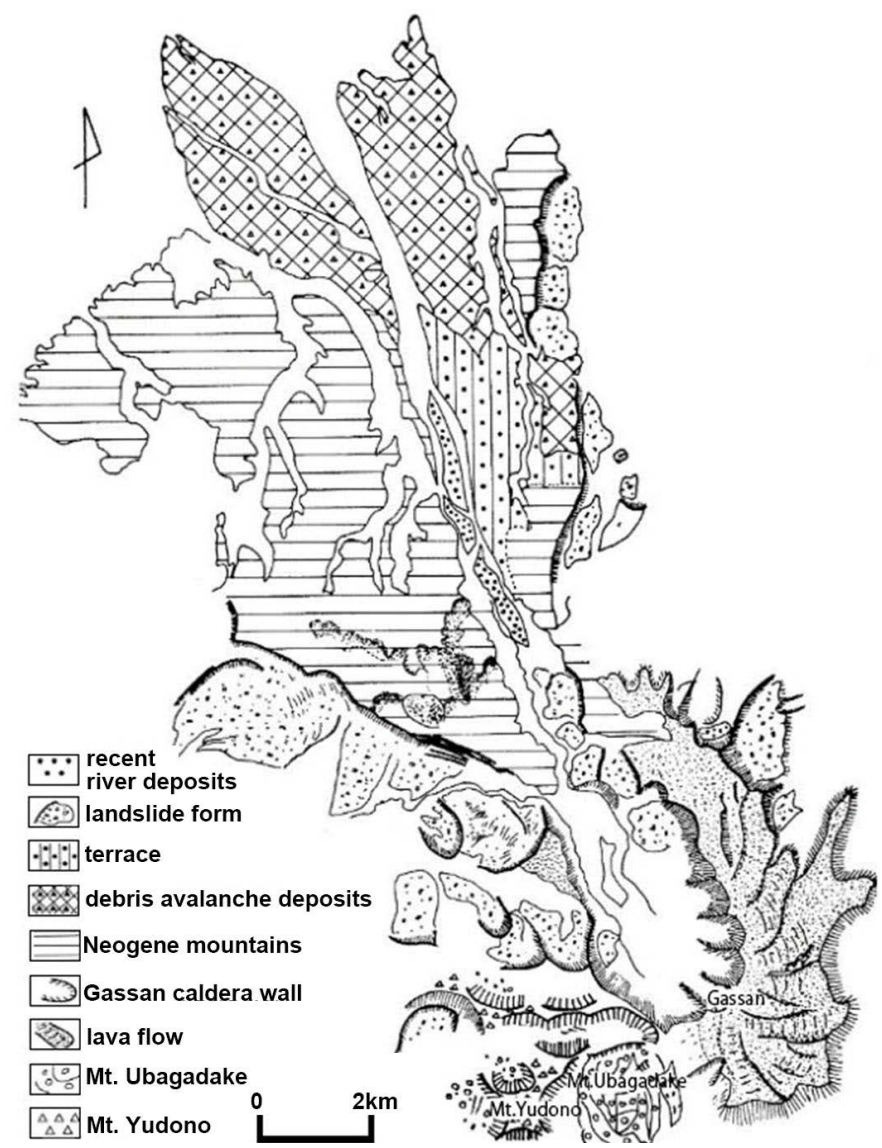

(a)

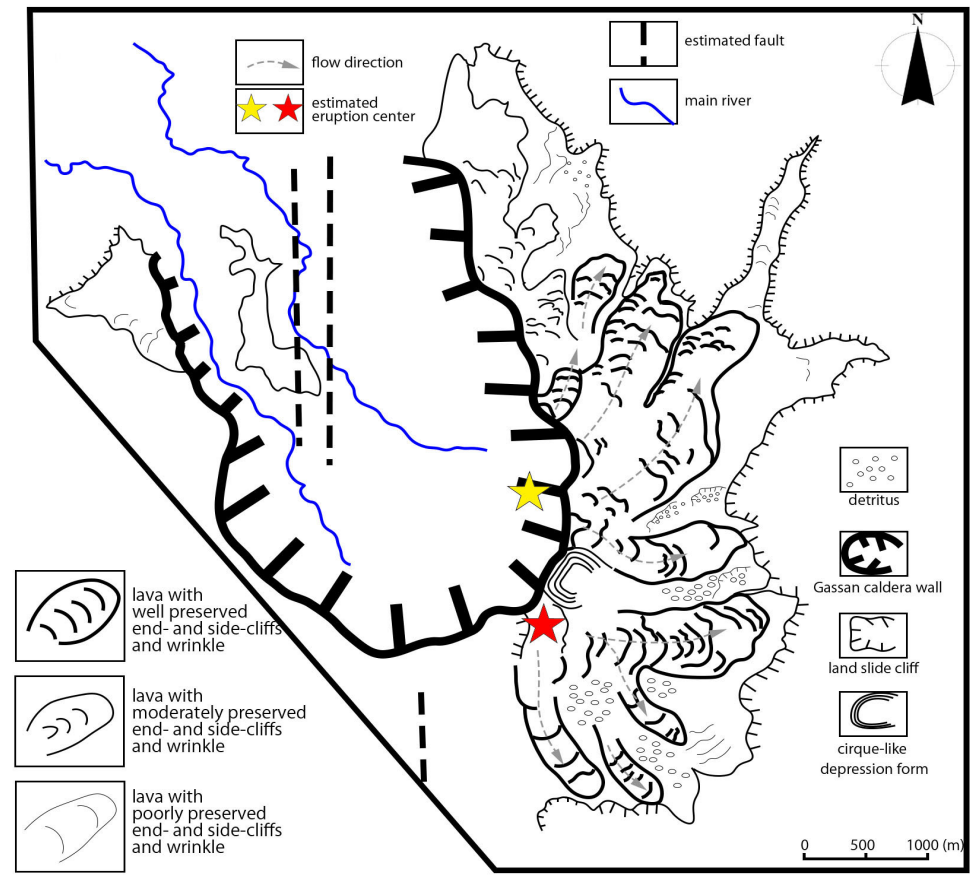

(b)

Figure 2. The Geomorphologic map of the Gassan volcano and surrounding area (a) and the close up of Gassan young edifice (b). The former is originally drawn by I. Moriya [22], partly modified. 
base diameter with relative heights of $\sim 30 \mathrm{~m}$ are still observable on the surface of the debris avalanche deposit. The farthest hummocky hill is recognized at $19 \mathrm{~km}$ north of the present summit. The total amount of the deposit is estimated at about ca. $1 \mathrm{~km}^{3}$.

The surface of the Gassan volcanic edifice, other than inner part of the caldera, can be divided into two areas [20]. One is flat and the other is dissected by erosion. The edifices with eroded and with flat surface are named as Gassan old and young ones, respectively.

Examining the geomorphology of the Gassan young edifice more closely, the young edifice can be further divided into two. One is the main area including the summit, where the end- and side-cliffs of lava flow are moderately preserved and the wrinkle of lava flow is sometimes observed. The other is the marginal area, where the end- and side-cliffs are obscure and the lava wrinkle is not preserved (Figure 2). By using the distribution of the end- and side-cliffs of the lavas in the main area, we can identify nine main flow lobes. Two are distributed in northern area. The lava wrinkle is relatively obscure on the northern two lobes, while it is well preserved on the other lobes (Figure 2(b)). The latter lobes flowed down to northeast (two lobes), east (two lobes), and southeast (three lobes). By using the flow direction of the seven lobes inversely (Figure 2(b)), we estimated the eruption center locations. As a result, the eruption center of the northern three lobes is estimated to be slightly northwest than that (near the present summit) of the other units (Figure 2(b)).

Additionally, cirque-like morphology is observed about 100 to $200 \mathrm{~m}$ northeastward from the summit, which would be originally formed in glacial age.

We note the rivers flow straightly inner part and southward outside of the Gassan caldera. These straight structures would be formed by fault activities. We will discuss these fault activities more detail in Section 7.

\section{Geology and Stratigraphy}

Geologic map is presented in Figure 3. The products are divided into lower and upper lavas based on the preservation of morphologic features described in Section 3. The lower lavas distribute in marginal area of the Gassan young edifice, whereas the upper lavas distribute in the main area. The upper lavas are sub-divided into upper north lavas and upper summit lavas in the ascending order, based on the preservation of surface morphology described in Section 3.

The Gassan lower lavas outcrop in the north-east-south of marginal parts of their distribution area and lower part of the east cliff of the Gassan caldera wall. Also, small distribution of lower lavas can be observed also in western part (Figure 3). In the northern area, two flow units can be identified by the distribution of lava end-cliff (Figure 3). In the land-slide cliff near the sampling point of 89092507 , the pile of three lavas can be observed. The thicknesses of the lavas are usually ca. 10 to $20 \mathrm{~m}$. Columnar joints are usually observed in the middle to the 


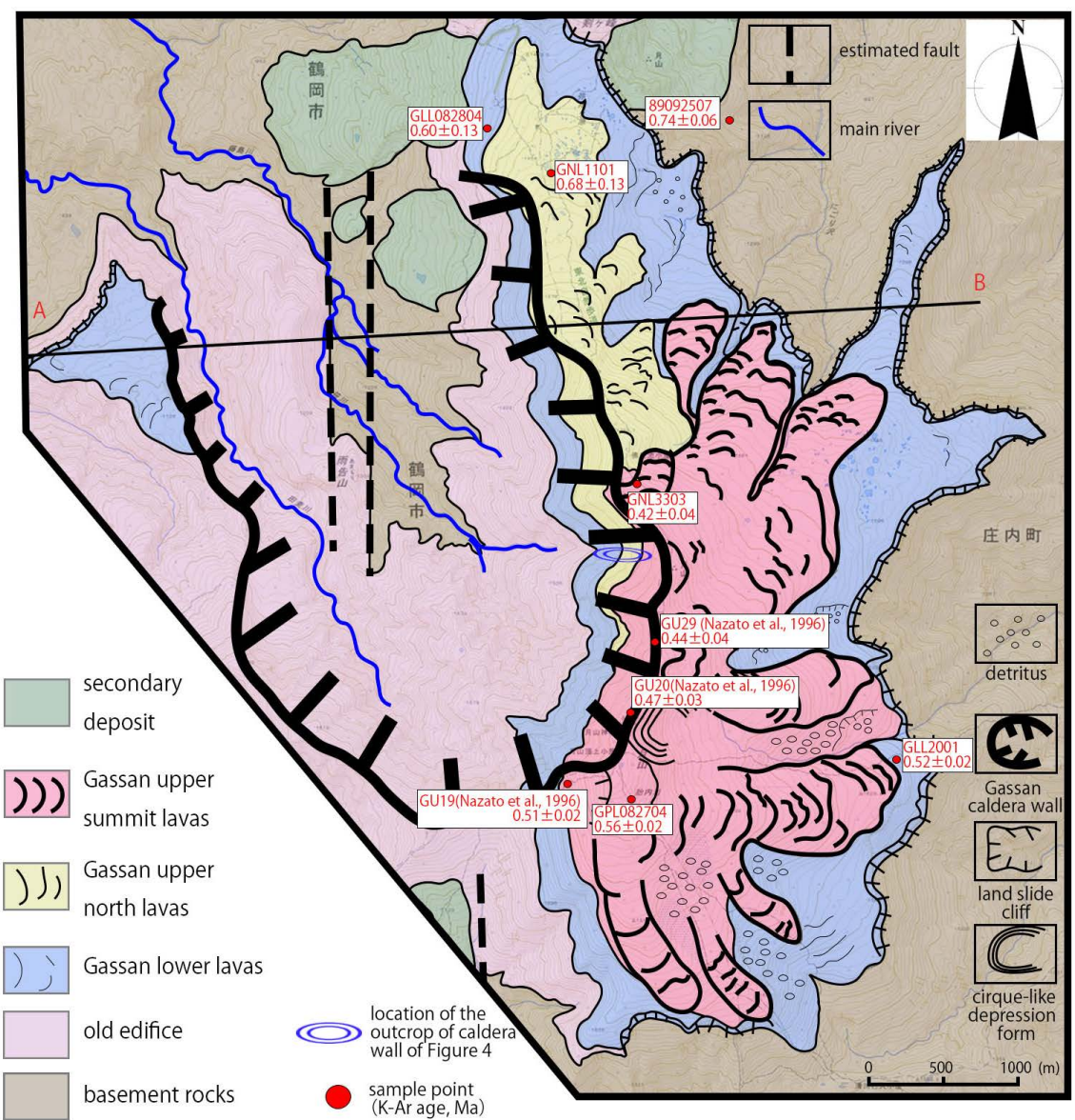

Figure 3. Geologic map of Gassan volcano. Sampling points with the ages of K-Ar dating are shown by red circles. Locations of K-Ar dating samples with the ages of [21] are shown by red circle. The locality of the outcrop of Figure 4 is indicated by a double circle. $\mathrm{A}$ and $\mathrm{B}$ are the points for the geologic section of Figure 7. The topographical map is from digital map 25,000 by Geospatial Information Authority of Japan.

top and the platy joints are observed in the bottom of the lavas. The lengths of the lavas are estimated to be ca. $4 \mathrm{~km}$, if the eruption center was near the present summit. The columnar section of a cliff of the caldera wall is presented in Figure 4. At the basal part of the outcrop of the caldera wall, the lava crinker part is observed, which is composed of reddish vesiculated blocks of $\sim 30 \mathrm{~cm}$ in length. Rocks of lower lavas, except for the lava crinker part, are pale blue colored andesite to dacite having plagioclase, orthopyroxene, and clinopyroxene phenocrysts. Quartz and hornblende are sometimes observed as phenocryst. Mafic inclusions (e.g., [23] [24]) can be observed in most of the lavas (Figure 5). These are light grey colored and usually less than $2.5 \mathrm{~cm}$ but sometimes up to several tens $\mathrm{cm}$ in size. These are usually rounded form and sometimes show irregular shape. The texture is diktytaxtic, containing abundant interstitial glasses with bubbles between laths of the plagioclase and pyroxene. The mafic inclusions are quenched products of mafic magmas which injected into intermediate to felsic magma chamber. 

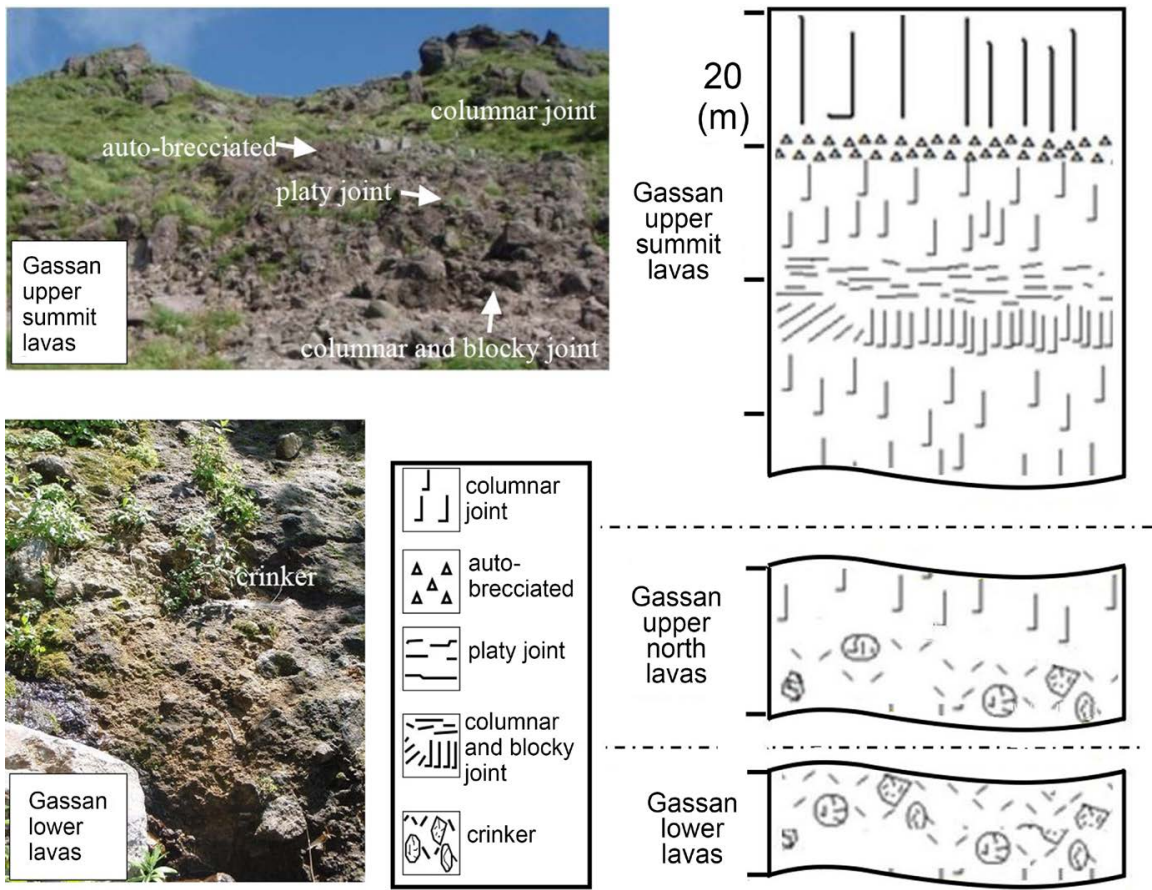

Figure 4. Columnar section of the outcrop of the caldera wall cliff. The location of the outcrop is shown in Figure 3.

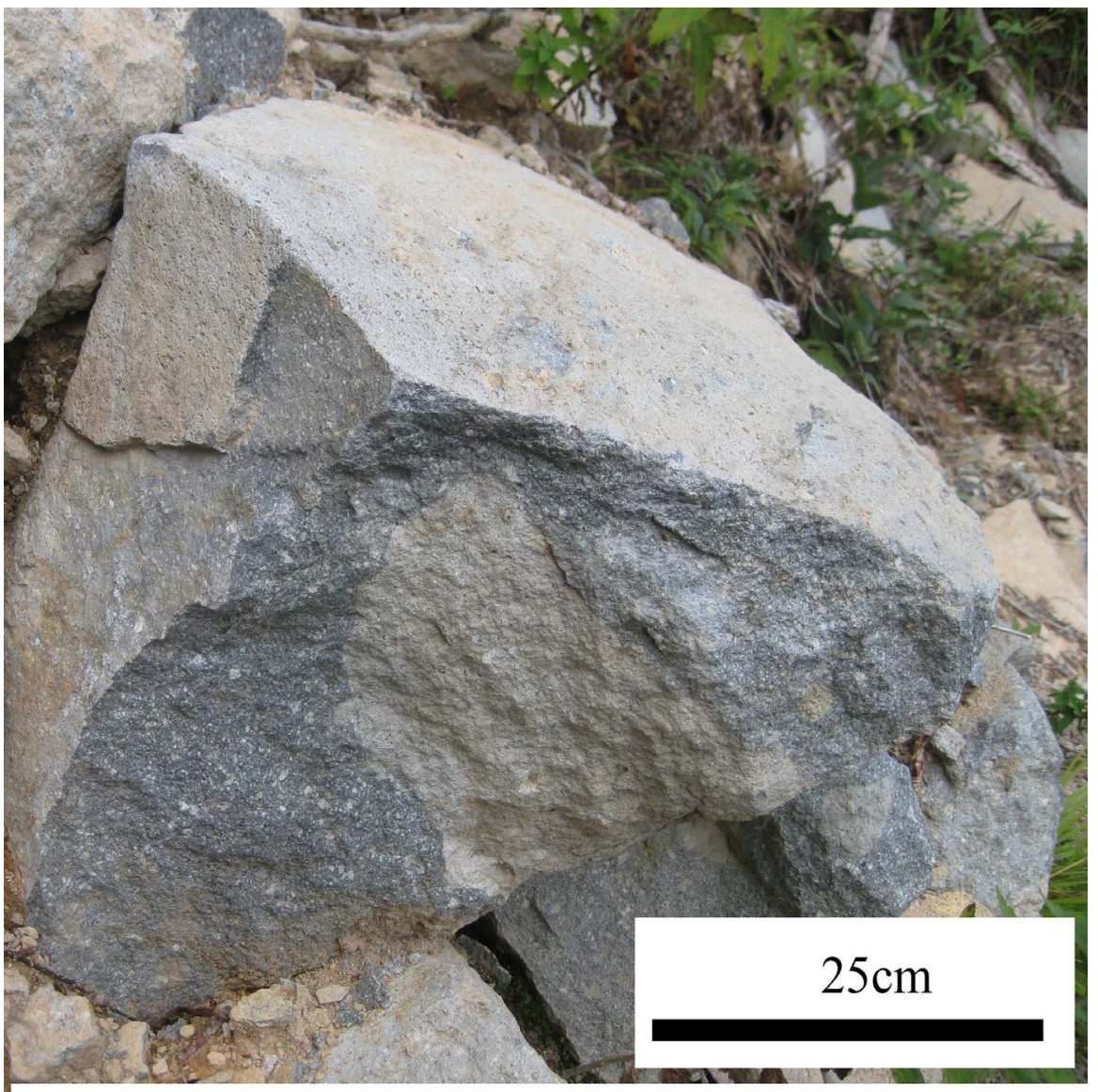

Figure 5. A photograph showing mafic inclusion in the upper summit lavas. 
The Gassan upper lavas outcrop in the cliffs of the caldera wall and scattered crop out on the flat surface. As described in Section 3, the lava wrinkle is relatively obscure in northern two lobes, while it is usually remarkable in the other lobes. We named the former as Gassan upper north lavas, and the latter as Gassan upper summit lavas. The stratigraphic relationships of Gassan upper north and summit lavas are observed in the outcrop of the caldera wall cliff (Figure 4).

Thicknesses of Gassan upper north and upper summit lavas observed in the outcrop of the caldera wall cliff are $>20 \mathrm{~m}$ and $70 \mathrm{~m}$, respectively. The thickness of Gassan upper summit lavas reaches about $250 \mathrm{~m}$ near the summit. The lengths of most of the lavas are estimated to be less than $2.5 \mathrm{~km}$. Columnar joint is sometimes observed in the middle to the top parts and the platy joint is observed in the bottom of the lavas. Rocks of Gassan upper lavas are pale blue colored andesite to dacite having plagioclase, orthopyroxene, clinopyroxene phenocrysts. Rare amount of olivine is observed in rocks of Gassan upper north lavas. Olivine, quartz, hornblende, biotite phenocrysts are sometimes observed in rocks of Gassan upper summit lavas. The mafic inclusions are observed in all lavas. Another remarkable feature is the banded structure, which is observed in a lobe distribution around the summit (Figure 6).

\section{K-Ar Dating}

We selected representative six samples from rocks from Gassan young edifice. All of these are lava samples. The sample descriptions are in Table 1. Samples were dated by Hiruzen Institute for Geology and Chronology using the K-Ar age determination, following the method [25] [26] [27]. K-Ar dating applied to groundmass concentrates of $187-250 \mu \mathrm{m}$ (60 - 80 mesh), most of the phenocrysts were removed using a magnetic separator [28]. Argon was analyzed by the isotope dilution method using an argon 38 spike [27]. The potassium contents were determined by flame photometry using a $2000 \mathrm{ppm}$ Cs buffer solution [25]. For K-Ar age calculation, the following constants, $\lambda_{\mathrm{e}}=0.581 \times 10^{-10}, \lambda_{\beta}=4.962 \times$ $10^{-10},{ }^{40} \mathrm{~K} / \mathrm{K}=0.0001167$ [29] were used. Replicate analyses of potassium content were reproducible within $2 \%$ [25], therefore, $2 \%$ error in potassium contents were used for age calculations. Errors in argon contents and $\mathrm{K}$-Ar ages represent 2 sigma.

The results are shown in Table 2. Ages of $0.74 \pm 0.06 \mathrm{Ma}$ and $0.60 \pm 0.13 \mathrm{Ma}$ for Gassan lower lavas, an age of $0.68 \pm 0.13 \mathrm{Ma}$ for Gassan upper north lavas, and ages of $0.42 \pm 0.04 \mathrm{Ma}, 0.52 \pm 0.02 \mathrm{Ma}$, and $0.56 \pm 0.02 \mathrm{Ma}$ for the Gassan upper summit lavas were obtained.

\section{Evolution History of Gassan Volcano}

The activity of the Gassan young edifice can be divided into early and late periods, which correspond to formation of Gassan lower and upper lavas.

The early period is characterized by the repeated effusions of relatively fluidal andesitic to dacitic lavas. The lavas would flow down to every direction from the 


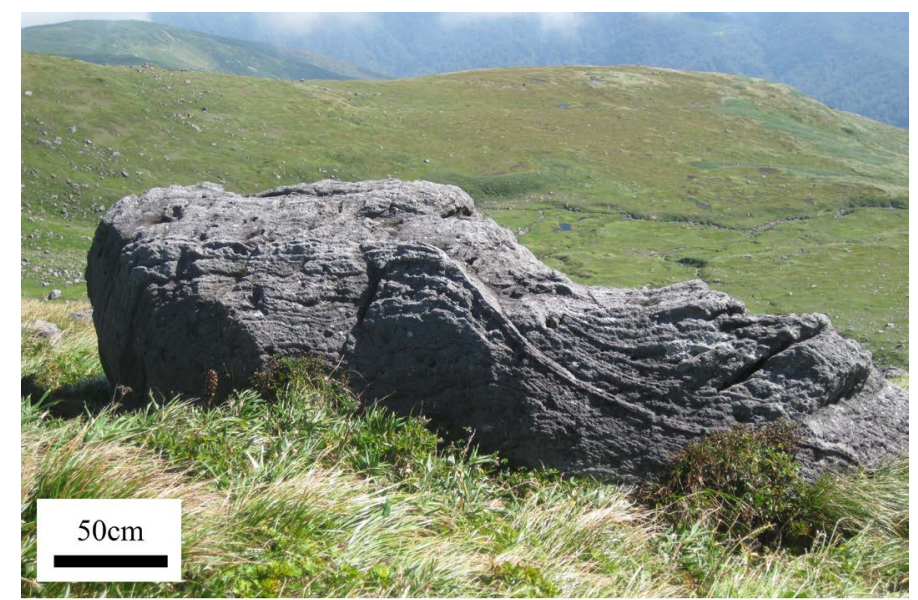

Figure 6. A photograph showing banded structure of the upper summit lavas.

Table 1. Summary of petrologic features of the dated samples.

\begin{tabular}{cccc}
\hline Sample name & Geologic unit name & Rock type & Groundmass texture \\
\hline GLL2001* & Gassan upper summit lavas & hbl bg. opx-cpx andesute & hyalo-ophitic \\
GNL3303 & Gassan upper summit lavas & olv-opx-cpx andesite & hyalo-ophitic \\
GPL82704 & Gassan upper summit lavas & bt-olv bg. opx-cpx andesite & hyalo-ophitic \\
GNL1101 & Gassan upper north lavas & bt-hbl-olv bg. opx-cpx andesite & hyalo-ophitic \\
GLL082804 & Gassan lower lavas & olv bg. opx-cpx andesite & hyalo-ophitic \\
89092507** & Gassan lower lavas & hbl-opx-cpx andesite & hyalo-ophitic \\
\hline
\end{tabular}

olv, olivine; opx, orthopyroxene; cpx, clinopyroxene; hbl, hornblende; bt, biotite; qtz, quartz; bg., bearing * a rolling stone from a lava lobe of Gassan upper summt lavas ca. $200 \mathrm{~m}$ westward from the sampling point. ** a rolling stone from of Gassan lower lavas exposed in the cliff ca. $500 \mathrm{~m}$ westward from the sampling point.

Table 2. Results of K-Ar dating of rocks from the Gassan volcano.

\begin{tabular}{|c|c|c|c|c|c|}
\hline $\begin{array}{l}\text { Sample } \\
\text { name }\end{array}$ & Geologic unit name & K (wt.\%) & Radiogenic $^{40} \mathrm{Ar}$ & $\begin{array}{c}\text { K-Ar age } \\
(\mathrm{Ma})\end{array}$ & $\begin{array}{l}\text { Non-radiogenic } \\
{ }^{40} \operatorname{Ar}(\%)\end{array}$ \\
\hline GLL2001 & $\begin{array}{l}\text { Gassan upper } \\
\text { summit lavas }\end{array}$ & $1.864 \pm 0.037$ & $\begin{array}{l}3.71 \pm 0.17 \\
3.80 \pm 0.16\end{array}$ & $\begin{array}{c}0.51 \pm 0.03 \\
0.53 \pm 0.02 \\
\text { av. } 0.52 \pm 0.02\end{array}$ & $\begin{array}{l}70.1 \\
69.1\end{array}$ \\
\hline GNL3303 & $\begin{array}{l}\text { Gassan upper } \\
\text { summit lavas }\end{array}$ & $2.394 \pm 0.048$ & $\begin{array}{l}3.94 \pm 0.54 \\
3.90 \pm 0.54\end{array}$ & $\begin{array}{c}0.42 \pm 0.06 \\
0.42 \pm 0.06 \\
\text { av. } 0.42 \pm 0.04\end{array}$ & $\begin{array}{l}89.3 \\
89.2\end{array}$ \\
\hline GPL82704 & $\begin{array}{l}\text { Gassan upper } \\
\text { summit lavas }\end{array}$ & $1.984 \pm 0.040$ & $\begin{array}{l}4.23 \pm 0.13 \\
4.34 \pm 0.14\end{array}$ & $\begin{array}{c}0.55 \pm 0.02 \\
0.56 \pm 0.02 \\
\text { av. } 0.56 \pm 0.02\end{array}$ & $\begin{array}{l}60.8 \\
59.7\end{array}$ \\
\hline GNL1101 & $\begin{array}{c}\text { Gassan upper } \\
\text { north lavas }\end{array}$ & $1.959 \pm 0.039$ & $5.15 \pm 1.01$ & $0.68 \pm 0.13$ & 92.4 \\
\hline GLL082804 & Gassan lower lavas & $1.946 \pm 0.039$ & $\begin{array}{l}4.53 \pm 1.46 \\
4.48 \pm 1.47\end{array}$ & $\begin{array}{c}0.60 \pm 0.19 \\
0.59 \pm 0.19 \\
\text { av. } 0.60 \pm 0.13\end{array}$ & $\begin{array}{l}95.3 \\
95.3\end{array}$ \\
\hline 89092507 & Gassan lower lavas & $1.779 \pm 0.036$ & $5.09 \pm 0.39$ & $0.74 \pm 0.06$ & 81.7 \\
\hline
\end{tabular}


eruption center, judged from the distribution area. The location of the center is difficult to estimate, but would be near the present summit, based on the lava distribution. The edifice would be like a small shield in shape with gentle slope. On the other hand, the late period is characterized by the repeated effusion of relatively viscus andesitic to dacitic lava. As a result, cone shaped edifice would be formed.

$\mathrm{K}$-Ar data of $0.74 \pm 0.06 \mathrm{Ma}$ and $0.60 \pm 0.13 \mathrm{Ma}$ were obtained from Gassan lower lavas. The former is from lower part of the Gassan lower lavas, whereas the latter is from upper part of them. Based on the former age, it is reasonable to consider that the early period would start around $0.75 \mathrm{Ma}$. The latter age has large error, thus it is difficult to deduce the age of the end of the activity. Here we pick the median value of $0.6 \mathrm{Ma}$ as the age. We conclude the early period would be from ca. 0.75 to ca. $0.6 \mathrm{Ma}$.

The obtained K-Ar age for the Gassan upper north lavas is $0.68 \pm 0.13 \mathrm{Ma}$. The obtained range ( 0.55 to $0.81 \mathrm{Ma}$ ) includes the age range of early period. But, it is stratigraphically evident that the Gassan upper north lavas are younger than the Gassan lower lavas. Thus, we conclude here that the age of the Gassan upper north lavas would be 0.6 to $0.55 \mathrm{Ma}$.

$\mathrm{K}$-Ar ages of $0.42 \pm 0.04 \mathrm{Ma}, 0.52 \pm 0.02 \mathrm{Ma}$, and $0.56 \pm 0.02 \mathrm{Ma}$ are obtained for the Gassan upper summit lavas. For the Gassan upper summit lavas, [21] already reported K-Ar ages of $0.44 \pm 0.04 \mathrm{Ma}, 0.47 \pm 0.03 \mathrm{Ma}$, and $0.51 \pm 0.02 \mathrm{Ma}$. Among these ages, younger ages $(0.42 \pm 0.04 \mathrm{Ma}$ and $0.44 \pm 0.04 \mathrm{Ma})$ are from the northern lobes, whose eruption center is estimated to be ca. $1 \mathrm{~km}$ northwest from present summit [21]. Whereas, older ages $(0.47 \pm 0.03 \mathrm{Ma}, 0.51 \pm 0.02 \mathrm{Ma}$, $0.52 \pm 0.02 \mathrm{Ma}$, and $0.56 \pm 0.02 \mathrm{Ma}$ ) are from the southern lobes, whose eruption center is estimated to be near present summit. Considering the error, some ages from northern lobes overlap with those from the southern lobes each other, but median values clearly split. It is possible to propose that the eruption center of near the present summit was active during ca. $0.55-0.5 \mathrm{Ma}$, thereafter the eruption center of ca. $1 \mathrm{~km}$ northwest from present summit was activated during ca. 0.5 - $0.45 \mathrm{Ma}$. The shift of eruption center location occurred at around 0.5 Ma. We note that we cannot exclude other possibilities, for example, obtained younger ages attribute to argon loss by weak weathering. However, we have no methods to evaluate the degrees of argon loss by weak weathering so far.

Using the estimated time spans and the eruption products volumes in each period, we estimated the averaged eruption rates of the early and late periods. The volume of the Gassan lower lavas was estimated supposing $20 \mathrm{~m}$ thick lavas distributed in the area of circle whose center is in $1.5 \mathrm{~km}$ northwest from present summit. The volume of the Gassan upper north lavas is difficult to estimate, because the lavas are distributing deviated to the north and the original form cannot be reconstructed. The volume of the Gassan upper lavas was estimated supposing two conical shaped edifices was formed, whose center are in the estimated two peaks. The calculated eruption rate are ca. $0.004 \mathrm{~km}^{3} / 1000$ years for early pe- 
riod and ca. $0.02 \mathrm{~km}^{3} / 1000$ years for the period of the Gassan upper summit lavas. These values are very low comparing available eruption rate data of Japanese stratovolcanoes $\left(0.29-0.54 \mathrm{~km}^{3} / 1,000\right.$ years: representative volcanoes in Kanto area [1]; $0.05-0.1 \mathrm{~km}^{3} / 1000$ years: those in Shinetsu area [30]; $0.05-0.08 \mathrm{~km}^{3} / 1000$ years: Nasu volcano [2]; ca. $0.15 \mathrm{~km}^{3} / 1000$ years: Chokai volcano [3]).

Obtained contrasting feature of the products between two periods, fluidal vs. viscus, would reflect magmatic temperature or the amounts of volatile components in magma. According to the petrologic study of the Gassan volcano by [20], the injection of mafic magma into shallow chamber filled with felsic magma triggered the eruption. However, T-P- $\mathrm{H}_{2} \mathrm{O}$ conditions of the mafic and felsic magmas were not defined. Detailed petrologic investigation on the lavas is necessary to seek the origin of the contrasting feature.

\section{Edifice Collapse and Fault Activity}

After the formation of cone shaped edifice, the caldera collapse occurred at the summit area. The debris avalanche flowed down to the north. The deposit having hummocky structure was formed. No juvenile fragments were found from the deposit [20], thus the collapse was not triggered by the magmatic eruption. The other possibility is fault activity. The active fault, named Shonai plain tohen fault zone, goes through beneath the Gassan volcano trending NS direction. The estimated faults shown in Figure 2 and Figure 3 would be south extension of the fault zone. The edifice collapse would relate to the activity of this fault zone. This fault is a reverse fault zone on the east side rise. Historical record of activity of this fault is in AD1894. The Shonai earthquake $(M=7.0)$ was by this activity and caused severe damage along the fault area [31]. This fault would be activated repeatedly over time, which resulted in uplift of the east side relative to the west side. The Gassan lower lavas distribute both on east and west side of the fault. The altitude of the surface of both sides is obviously different (Figure 7). The gap of the altitude is about $300 \mathrm{~m}$. The age of the Gassan lower lava 3 is estimated to be ca. $0.7 \mathrm{Ma}$, thus the east side uplift rate is calculated to be ca. 0.04 $\mathrm{cm} /$ year. This value is similar to that estimated one for the displacement of the Shonai plain tohen fault zone by The Headquarters for Earthquake Research Promotion [32]. Several old volcanoes are distributing near the fault other than the Gassan volcano in this area. Collapse terrains can be observed in these volcanoes [33]. It is probable that the activity of the fault will cause another collapse in the future.

\section{Conclusions}

We examined the evolution history of the young edifice geologically, based on geomorphological and lithological data coupled with new K-Ar data and obtained following results.

1) The eruption products can be divided into lower and upper lavas based on the preservation of morphologic features. The upper lavas can be further divided into Gassan upper north lavas and Gassan upper summit lavas. 


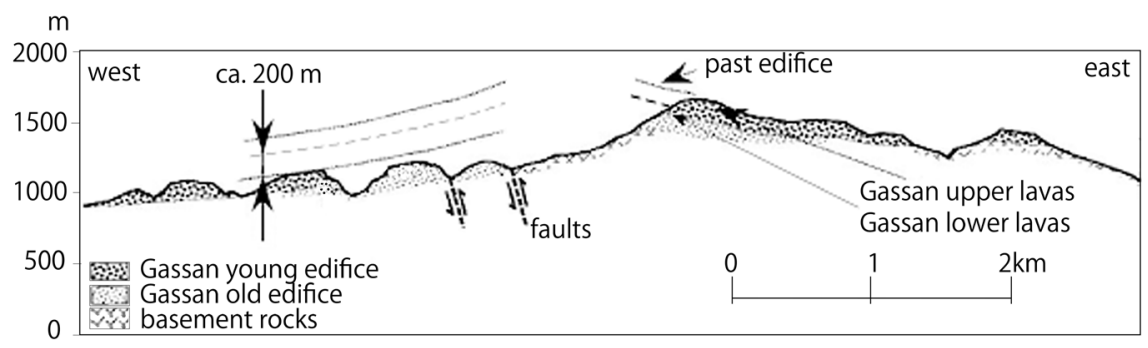

Figure 7. Geologic section of Gassan volcano along A-B line shown in Figure 3.

2) The early period (activity of Gassan lower lavas) is characterized by the repeated effusions of relatively fluidal andesitic to dacitic lavas. The lavas would flow down to every direction from the eruption center, judged from the distribution area. The location of the center would be near the present summit based on the lava distribution. The edifice would be like a small shield in shape with gentle slope. On the other hand, the late period (activity of Gassan upper lavas) is characterized by the repeated effusion of relatively viscus andesitic to dacitic lava. As a result, cone shaped edifice would be formed.

3) The ages of Gassan lower lavas, Gassan upper north lavas, and Gassan upper summit lavas were estimated to be ca. 0.75 to ca. $0.6 \mathrm{Ma}, 0.6$ to $0.55 \mathrm{Ma}$, ca. 0.55 to $0.45 \mathrm{Ma}$. The calculated eruption rates are ca. $0.004 \mathrm{~km}^{3} / 1000$ years for Gassan lower lavas period and ca. $0.02 \mathrm{~km}^{3} / 1000$ years for Gassan upper summit lavas period.

4) After the formation of the thick lavas (Gassan upper lavas), horse-shoe shaped Gassan caldera was formed by the instability of the edifice, probably triggered by fault activity. The estimated average rate of east side uplift of the fault is ca. $0.04 \mathrm{~cm} /$ year.

\section{Acknowledgements}

We are grateful to anonymous reviewer for giving constructive comments on the early version of the manuscript. We also express hearty thanks to Prof. M. Ishikawa for joining research group of studies on crustal structure beneath strain concentration zone around eastern margin of Japan Sea. This work was financially supported in part by a Grant-in-Aid for Scientific Research from the Japan Society for the Promotion of Science to Prof. M. Ishikawa (No. 23340153). Profs K. Nakashima and J. Yokoyama gave us constructive suggestions on this study. Dr. K. Yagi of the Hiruzen Institute for Geology and Chronology kindly gave us useful information about $\mathrm{K}-\mathrm{Ar}$ dating. We are also grateful to the Haguro Nature Conservation Office of Ministry of the Environment of Japan for providing permission to survey national parks.

\section{References}

[1] Moriya, I. (1983) Geomorphology of Japanese Volcanoes. Tokyo University Press, Tokyo, $135 \mathrm{p}$.

[2] Ban, M. and Takaoka, N. (1995) Evolutionary History of the Nasu Volcano Group, 
Northeast Japan Arc. Journal of Mineralogy, Petrology and Economic Geology, 90, 195-214. https://doi.org/10.2465/ganko.90.195

[3] Ban, M., Hayashi, S. and Takaoka, N. (2001) K-Ar Dating of the Chokai Volcano, Northeast Japan Arc: A Compound Volcano Composed of Continuously Established Three Stratovolcanoes. Bulletin of the Volcanological Society of Japan, 46, 317-333.

[4] Ishizuka, Y. (1999) Eruptive History of Rishiri Volcano, Northern Hokkaido, Japan. Bulletin of the Volcanological Society of Japan, 44, 23-40.

[5] Ban, M., Ohba, T. and Fujinawa, A. (2013) B0l: Active Volcanoes in Northeast Japan, 2013 IAVCEI Field Trip Guide. Bulletin of the Volcanological Society of Japan, 58, B1-1-B1-34.

[6] Hayashi, S., Umeda, K., Ban, M., Sasaki, M., Yamamoto, M., Ohba, T., Akaishi, K. and Ohguchi, T. (1996) Temporal and Spatial Distribution of Quaternary Volcanoes, Northeastern Japan (1), Spreading of Volcanic Area toward Back-Arc Side. Volcanological Society of Japan Abstracts of the 1996 Meeting, 2, 88.

[7] Umeda, K., Hayashi, S., Ban, M., Sasaki, M., Ohba, T. and Akaishi, K. (1999) Sequence of the Volcanism and Tectonics during the Last 2.0 Million Years along the Volcanic Front in Tohoku District, NE Japan. Bulletin of the Volcanological Society of Japan, 44, 233-249.

[8] Tamura, Y., Tatsumi, Y., Zhao, D., Kido, Y. and Shukuno, H. (2001) Distribution of Quaternary Volcanoes in the Northeast Japan Arc: Geologic and Geophysical Evidence of Hot Fingers in the Mantle Wedge. Proceedings of the Japan Academy, 77, 135-139. https://doi.org/10.2183/pjab.77.135

[9] Kondo, H., Nakeko, K. and Tanaka, K. (1998) Characterization of Spatial and Temporal Distribution of Volcanoes since $14 \mathrm{Ma}$ in the Northeast Japan Arc. Bulletin of the Volcanological Society of Japan, 43, 173-180.

[10] Tamura, U., Tatsumi, Y., Zhao, D., Kido, Y. and Shukuno, H. (2002) Hot Fingers in the Mantle Wedge: New Insights into Magma Genesis in Subduction Zones. Earth and Planetary Science Letters, 197, 105-116. https://doi.org/10.1016/S0012-821X(02)00465-X

[11] Nakajima, J., Matsuzawa, T., Hasegawa, A. and Zhao, D. (2001) Three-Dimensional Structure of Vp, Vs and Vp/Vs Beneath Northeastern Japan Arc: Implications for Arc Magmatism and Fluids. Journal of Geophysical Research, 106, 21843-21857. https://doi.org/10.1029/2000JB000008

[12] Wang, Z. and Zhao, D. (2005) Seismic Imaging of the Entire Arc of Tohoku and Hokkaido in Japan Using P-Wave, S-Wave and SP Depth-Phase Data. Physics of the Earth and Planetary Interiors, 152, 144-162. https://doi.org/10.1016/j.pepi.2005.06.010

[13] Huang, Z., Zhao, D. and Wang, L. (2011) Seismic Heterogeneity and Anisotropy of the Honshu Arc from the Japan Trench to the Japan Sea. Geophysical Journal International, 184, 1428-1444. https://doi.org/10.1111/j.1365-246X.2011.04934.x

[14] Kuno, H. (1966) Lateral Variation of Basalt Magma Type across Continental Margins and Island Arcs. Bulletin of Volcanology, 29, 195-222.

https://doi.org/10.1007/BF02597153

[15] Kawano, Y., Yagi, K. and Aoki, K. (1961) Petrography and Petrochemistry of the Volcanic Rocks of Quaternary Volcanoes of Northeastern Japan. Science Reports of Tohoku University Ser III, 7, 1-46.

[16] Sakuyama, M. and Nesbitt, R.W. (1986) Geochemistry of the Quaternary Volcanic 
Rocks of the Northeast Japan Arc. Journal of Volcanology and Geothermal Research, 29, 413-450. https://doi.org/10.1016/0377-0273(86)90053-3

[17] Nakagawa, M., Shimotori, H. and Yoshida, T. (1988) Across-Arc Compositional Variation of the Quaternary Basaltic Rocks from the Northeast Japan Arc. Journal of Mineralogy, Petrology and Economic Geology, 83, 9-25. https://doi.org/10.2465/ganko.83.9

[18] Tatsumi, Y., Sakuyama, M., Fukuyama, H. and Kushiro, I. (1983) Generation of Arc Magmas and Thermal Structure of the Mantle Wedge in Subduction Zones. Journal of Geophysical Research, 88, 5815-5825. https://doi.org/10.1029/JB088iB07p05815

[19] Tatsumi, Y. and Eggins, S. (1995) Subduction Zone Magmatism. Blackwell, Oxford, $211 \mathrm{p}$.

[20] Inoue, K. and Ban, M. (1996) Petrology of Younger Stage Lavas from the Gassan Volcano, Northeastern Japan. Journal of Mineralogy, Petrology and Economic Geology, 91, 33-47. https://doi.org/10.2465/ganko.91.33

[21] Nakazato, H., Oba, T. and Itaya, T. (1996) The Geology and K-Ar Ages of the Gassan Volcano, Northeast Japan. Journal of Mineralogy, Petrology and Economic Geology, 91, 1-10. https://doi.org/10.2465/ganko.91.1

[22] Ban (2005) Gassan. In: Koike, K., Tamura, T., Chinzei, K. and Miyagi, T., Eds., Regional Geomorphology of the Japanese Islands, Vol. 3 Geomorphology of Tohoku Region, University of Tokyo Press, Tokyo, 274-276.

[23] Eichelberger, J.C. (1978) Andesite Volcanism and Crustal Evolution. Nature, 275, 21-27. https://doi.org/10.1038/275021a0

[24] Bacon, C.R. (1986) Magmatic Inclusions in Silicic and Intermediate Volcanic Rocks. Journal of Geophysical Research, 91, 6091-6112. https://doi.org/10.1029/JB091iB06p06091

[25] Nagao, K., Nishido, H., Itaya, T. and Ogata, K. (1984) An Age Determination by K-Ar Method. Bulletin of the Hiruzen Research Institute, Okayama University of Science, 9, 19-38.

[26] Nagao, K. and Itaya, T. (1988) K-Ar Age Determination. Memoirs of the Geological Society of Japan, 29, 5-21.

[27] Itaya, T., Nagao, K., Inoue, K., Honjou, Y., Okada, T. and Ogata, A. (1991) Argon Isotope Analysis by a Newly Developed Mass Spectrometric System for K-Ar Dating. Mineral Journal, 15, 203-221. https://doi.org/10.2465/minerj.15.203

[28] Yagi, K. (2006) Manual of Mineral Separation for K-Ar Dating. Engineering Geology of Japan, 0 (The Special Issue of 10th Anniversary of Hiruzen Institute for Geology and Chronology), 19-25.

[29] Steiger, R. and Jäger, E. (1977) Subcommission on Geochronology Convention on the Use of Decay Constants in Geo- and Cosmochronology. Earth and Planetary Science Letters, 36, 359-362. https://doi.org/10.1016/0012-821X(77)90060-7

[30] Kaneko, T., Shimizu, S. and Itaya, T. (1989). K-Ar Chronological Study of the Quaternary Volcanic Activity in Shin-Etsu Highland. Journal of Mineralogy, Petrology and Economic Geology, 84, 211-225. https://doi.org/10.2465/ganko.84.211

[31] Suzuki, Y., Ikeda, Y., Watanabe, M., Sugai, T. and Yonekura, N. (1989) Holocene Activity of the Eastern Boundary Gault of the Shonai Plain, Northeast Japan, and Its Implications for the Shonai Earthquake of 1894-Excavation of the Kannonji Fault. Zisin (Journal of the Seismological Society of Japan), 42, 151-159.

[32] The Headquarters for Earthquake Research Promotion (2009) Partly Revision of Long-Term Evaluation of the Shonai-Tohen Fault Zone, Earthquake Survey Com- 
mittee, Ministry of Education and Technology Japan. 41 p.

[33] Matsuda, T., Ban, M. and Ohba, Y. (1997) Petrological Characteristics of Two Types of Inclusions and Their Host Rocks from the Yudonosan Volcano, Southern Part of the Chokai Zone, Northeast Japan. Journal of Mineralogy, Petrology and Economic Geology, 92, 245-259. https://doi.org/10.2465/ganko.92.245 